subscriptions was headed by a gift of $£ 10,000$ from Sir Robert Hadfield, to whom the University was already indebted for valuable donations and much support. It is now announced that Sir Robert has increased his donation to $£ 20,000$, this being the largest individual gift so far received in answer to the appeal. The announcement was made in the course of his address at the annual meeting last month of Messrs. Hadfields, Ltd., and Sir Robert added that he was moved to add to his original donation by the noteworthy address delivered early last March by General Smuts on "The University in Civic Training", when he was installed as Chancellor of the University of Cape Town. General Smuts believes that the university is the hope of civilization, the one place where fact is exalted above sectional loyalties and ideologies. Sir Robert has given substantial proofs that he, likewise, has faith in the university as an institution of vital significance for the future of humanity. It is to be hoped that his great benefactions to the University of Sheffield will stimulate other industrialists to play their part in supporting more liberally, if not universities in general, at least the particular university to which they must look for development and progress in their own field. Sir Robert Hadfield, it may be noted, celebrated the fiftieth anniversary of his election to the Institution of Civil Engineers on March 1, when he received a congratulatory address from the president, and on March 23 was elected an honorary member of the Institution, for his "long and conspicuous service in the advancement of metallurgical science".

\section{Decorative Lighting for the Coronation}

SINCE the last coronation, twenty-six years ago, great improvements have taken place in the art of decorative lighting. In 1911, metal filament and arc lamps were used. Since then the invention of gasfilled lamps and the development of electric-discharge lamps have greatly cheapened the cost and improved the flexibility of the illumination. The illuminations will show many new aspects of London, and practically all the principal provincial cities will have very effective displays. In London alone there will be nearly two hundred floodlighting installations, and in the provinces, statistics obtained from six hundred local authorities show that the mean additional load per town will be approximately 60 kilowatts. This does not take into account the numerous smaller schemes of strip-lighting and illuminated devices with which shops and business premises will be decorated. For the first time, the fountains in Trafalgar Square are being illuminated by means of eight submersible reflectors taking 500-watt gas-filled lamps. In addition to all four sides of 'Big Ben', the terrace of the Houses of Parliament is being flood. lighted for the first time. Two novelties are, $30-\mathrm{ft}$. high electric 'bonfires' with flame effects on the roof of the Shell Mex House, and colour changing equipment for illuminating $30-\mathrm{ft}$. high jets of water from fire floats stationed outside the new London Fire Brigade headquarters. A very large sodium flood- lighting installation used at Dunfermline Abbey and Edinburgh Castle give an outstanding and beautiful display of decorative lighting.

\section{The German Airship Disaster}

THE latest and largest German airship, Hindenburg, was destroyed by fire while landing at Lakehurst, New Jersey, U.S.A., on the evening of May 6. This was the terminal point of her first voyage of the year from Frankfort-on-Main. She carried 39 passengers and 61 crew, approximately half of whom were killed or afterwards died of injuries. The airship had been cruising about for an hour during a heavy storm, which was judged to be too severe for safe landing, and was just coming in at about 300 feet above the ground, dropping her nose mooring lines for the landing crew on the flying field. Reports state that a burst of flame was seen at the stern. In a few moments the whole ship was enveloped in fire. This was evidently due to the ignition of the hydrogen in the gas bags, as the report mentions the exceptional brilliance of the fire. No details are yet avail. able upon which any useful theories as to the cause of the fire can be based, but the fact that the ship had been cruising around the field in a heavy thunderstorm lends colour to the suggestion that she was electrically charged, and raises the possibility of sparks having occurred when the landing ropes earthed her. It is known that special precautions against this were embodied in her design, and therefore this theory assumes some additional accident. Whatever was the original cause of the accident, it is certain, as was the case with the British airship $R$ 101, that the ignition of the highly inflammable hydrogen was responsible for the completeness of the disaster.

\section{The Electrical Industry of the World}

THE twenty-ninth report of the Imperial Economic Committee (London : H.M. Stationery Office. $2 s .6 d$. net) gives a survey of the trade in electrical machinery and apparatus. The latest information given relates to the year 1935. Perhaps the most significant feature during the last five years is the leading part that radio receiving sets have been occupying. At the end of 1935 there were 56 million sets of this type of apparatus in use, the increase having nearly doubled in five years. There were 22.5 million sets installed in the United States, and this works out to 178 per 1,000 of the population. The consumption of electrical energy used in radio receiving was 1,540 million kilowatt hours per annum. The corresponding figures for Great Britain, which was second in the world's list, was 7.4 million sets, and the third was Germany with $7 \cdot 2$ million. On the other hand, the increase in the world's telephones was comparatively small. This is ascribed primarily to an actual decrease in the United States and Canada. But these two countries still lead in this form of communication. It is worthy of note that there is a greater number of telephones per head of population in agricultural countries like Denmark, New Zealand and Australia, than there is in industrial 
countries such as Great Britain, Germany and France. Probably this is due to the greater facilities of communication by other methods in the latter countries. Russia has come to the front as an electrical manufacturing country. This is shown by the fact that the value of its imports, which rose gradually from 3.62 million pounds in 1929 to $9 \cdot 15$ million pounds in 1932, has fallen rapidly to only $£ 789,000$ in 1935 . The outstanding example of self-sufficiency is the United States, the imports of which in 1935 were valued at only $£ 427,000$.

\section{Present State of British Bird Ringing}

The 1936 report on bird ringing in the British Isles (British Birds, April 1937) supports what the 1935 report indicated, namely, that future progress lies not in increasing the sum total, but rather in increasing the proportion of adult birds over nestlings, and scarcer species, marked. Although the total of 48,663 birds ringed is below the number for previous years, the total of trapped adult birds, 19,235, is a record, while that for nestlings (where mortality is naturally high) of 29,428 is a decline on the previous years. Dr. H. J. Moon again heads the list of ringers with 5,280 birds ringed, including 1,332 lapwings, 975 song thrushes, 849 blackbirds and 587 starlings; Mr. G. Charteris marked 3,524 birds, 1,166 of which were chaffinches, and Mr. E. Cohen marked 3,024 birds, including 865 shearwaters. There is an increasing number of birds ringed by schools and societies, and the two bird observatories. The Oxford Ornithological Society marked 2,639 birds, Bootham School 1,656, Rugby School 1,050, the Midlothian Ornithological Club 813, the British Empire Naturalists' Association 158, the Zoological Society 511 and Leighton Park School 403. Totals of ringed birds are not quite so significant as the numbers of birds of rarer species marked. Among the ringings of the Oxford Ornithological Society, for example, were 67 kingfishers, Skokholm Bird Observatory marked 27 white wagtails and 20 Greenland wheatears, Mr. A. Maynall marked 409 nightingales, Mr. C. Wontner Smith marked 201 rooks, Rugby School marked 169 rooks and 62 carrion-crows, Leighton Park School marked 21 fork-tailed petrels, Dartington Hall School 12 cirl buntings, the Isle of May Bird Observatory a barred warbler, two bluethroats and a Continental coal tit. Of the national total, the most numerous species ringed were : 3,191 lapwings, 2,155 Manx shearwaters, 1,530 Sandwich terns, 1,271 common terns and 1,131 herring-gulls.

\section{The National Institute of Agricultural Botany}

THE seventeenth report of the National Institute of Agricultural Botany, Cambridge, is now available, and copies may be obtained on application to the Institute (Huntingdon Road, Cambridge). The work of the Institute is directed to supplying the farmer with unbiased information as to the seeds he sows, and the report deals with methods by which this information was obtained in 1936. New varieties of all farm crops are tested by the Institute as soon as they appear, the trials being conducted on a field- scale at six permanent stations in England, and in some cases at additional centres on a farmer's own land. In all cases, the varieties are grown just as they would be by the farmer himself. Every feature of the varieties is noted and the results are often extremely enlightening. For example, of all the new varieties of winter wheat that have been tested in the last ten years, only one has proved to be worthy of general recommendation by the Institute. This is the Dutch variety 'Juliana', which has in the past two years' trials given slightly better results than 'Wilhelmina'. The position with other crops is very similar, and it is clear that farmers will be well advised, before deciding to grow a new variety, to apply to the agricultural organizer for their county, or direct to the Institute, for information as to the merits of the variety in question.

\section{"The Hero"}

LORD RAGLAN writes in reference to the review of his book "The Hero" appearing in NATURE (March 27, p. 532) : "Your reviewer . . suggests that in the absence of documentary evidence $I$ would feel constrained to deny the existence of Nelson and Napoleon. My contention is that in the absence of documentary evidence we should none of us have heard of Nelson and Napoleon." In reply, the reviewer says that, in effect, Lord Raglan appears to agree. In so far as Nelson and Napoleon are characters in the folk drama, they stand on the same footing as Robin Hood, Maid Marian and the rest. These two names, however, were not an effort of invention, but were chosen as those of the popular hero and bogey of the day. Their survival in this form is an effect of folk memory and not of documentary evidence, and their appearance in a ritual does not preclude their real existence, however incongruous their dramatic action. In this instance, the inference happens to be supported by documentary evidence. The conclusion to the contrary, however, that is, that without documentary evidence we should not know of their existence, is shown not necessarily to hold good. Approved documentary evidence is the only source of certain knowledge, and to this extent Lord Raglan is above criticism; but the archæologist maintains, on the other hand, that a legend may embody facts which may in certain conditions afford a clue to interpretation, when his evidence points in a certain direction. The story of the Minotaur may be ritualistic ; but the setting of the Minoan civilization is the fact to which it gave Sir Arthur Evans the clue. It may be true that, strictly speaking, in the absence of documentary evidence we have no certain knowledge of Minos; but we have all heard and believe in the existence of the head of the great empire, for whom his name is the generic term.

\section{Russian Railway Transport}

AT the International Exhibition of Art and Technique in Modern Life which is to be opened in Paris this month, Soviet railway transport will be well represented, the principal exhibit being a working 